\title{
RE-AKTUALISASI KENDIL HITAM
}

\author{
Koniherawati \\ Centaury Harjani
}

\begin{abstract}
ABSTRAK
"Hidup Segan Matipun Tak Mau" adalah ungkapan yang tepat untuk menggambarkan kondisi kembang-kempisnya hidup kerajinan gerabah tradisional di beberapa daerah, khususnya kerajinan kendil hitam di desa Kasongan, Kendil hitam dikenal dengan sebutan kendil gudeg, kendil ini biasa digunakan sebagai wadah makanan khas Jogja yaitu gudeg. Kendil dihasilkan oleh pengerajin gerabah melalui proses pembuatan secara "tradisional". Pembuatan kendil hitam sangat tradisional menggunakan bahan tanah liat yang terdapat di alam sekitar, menggunakan peralatan sederhana, serta pembakaran ladang (field firing) suhu rendah berbahan bakar uwuh (daun-daundan ranting kering). Kendil sebagai wadah yang aman untuk makanan. Teknik seni gerabah tradisional ini sudah dikenal sebagai ciptaan manusia sejak jaman prasejarah untuk membuat barang kebutuhan sehari-hari dalam bertahan hidup (life survival). Teknik pembuatan tradisional diwariskan secara turun-temurun oleh nenek moyang, dan saat ini dan mulai bersaing dengan produk industri yang dibuat secara massal. Tulisan ini akan mengangkat keistimewaan kendil hitam dalam bertahan hidup memenuhi kebutuhan untuk wadah makanan gudeg di jaman milenial ini. Studi pustaka, observasi, dan wawancara dengan pendekatan etnografi digunakan sebagai metode penelitian. Hasil dari penelitian diharapkan berguna untuk melengkapi pengetahuan akademik khususnya bagi mahasiswa jurusan keramik, yang selama ini hanya mengenal pembuatan keramik modern dengan peralatan canggih (modern).
\end{abstract}

Kata Kunci: gerabah tradisional, bertahan hidup, era milenial.

\begin{abstract}
"Hidup Segan Matipun Tak Mau" is an expression that describes the struggling conditions of conserving traditional pottery crafting in several regions, especially black kendil in Kasongan village. This black kendil, known as gudeg kendil, is commonly used as a container used for storing one of Jogja's most traditional dish, namely gudeg. Kendil is produced by pottery craftsmen through a "traditional" manufacturing process. Black kendil is traditionally made out of clay that is discovered easily in surroundings areas, and by using simple equipment, that is then burnt in the field with low-temperature (field firing) using dried leaves and twigs (uwuh) to produce containers that are food-safe. This traditional pottery art technique has been known as one of human's creations used in order to produce daily necessities for life survival since the pre-historic times. These traditional manufacturing techniques have been passed down from ancestors to the current generation, and now competes with mass industrial production. This paper will highlight the features of maintaining the use of black kendil as gudeg food containers in this current millennial era. Literature studies, observations, and interviews with the ethnographic approach are used as the methods of research. The results of the study are expected to be useful for academics, particularly students of ceramics major, who are more exposed to modern ceramic manufacturing through the use of advanced equipment.
\end{abstract}

Key-word: traditional pottery, life survival, millenial era. 


\section{PENDAHULUAN}

Gerabah tradisional sangat menarik untuk diamati, terutama awal diciptakannya sebagai fungsi melengkapi peralatan dapur dalam manusia bertahan hidup (life survival). Manusia mulai membuat peralatan rumah tangga setelah hidup menetap dan bercocok tanam. Manusia purba mulai membuat peralatan rumah tangga, diantaranya dari bahan yang mereka temukan di alam seperti: batu dan tanah liat. Peralatan rumah tangga dari tanah liat yang dibuat berupa: wajan (sangan), kwali, kendil, cobek (lepek), luweng (pawon) tungku tanah sederhana kemudian berkembang bentuk kern dan anglo. Ketertarikan akan dunia gerabah mulai mucul sejak penulis menyadari bahwa kehidupan manusia modern tidak lepas dari perkembangan peradaban manusia purba. Awalnya alat-alat diciptakan manusia dengan tujuan untuk upacara keagamaan (alat ritual) kemudian peralatan untuk fungsi memasak, makan dan minum. Alat-alat diciptakan melalui proses penyesuaian diri manusia terhadap alam sekitarnya dengan teknik yang sangat sederhana. Melalui penemuan para ahli arkheologi dapat dipelajari cara hidup manusia purba, yaitu melalui benda-benda artefak yang ditemukan, seperti kapak, tombak dan pisau dari batu, benda-benda yang terbuat dari tanah liat: gerabah. Dari penemuan arkheologi, gerabah merupakan salah satu artefak penting dalam mengenal peradaban manusia saat itu. Beberapa penemuan berupa alat ritual keagamaan dan alat memasak, seperti: tempat sesaji, tempat abu jenazah atau macam-macam bentuk periuk untuk memasak (kuali, kendil dan piring) dan tempat air (tempayan).

Pembuatan gerabah untuk kebutuhan perlengkapan dapur, makan dan minum hingga saat ini masih dapat kita jumpai di beberapa daerah di Indonesia dan negara lain. Salah satu daerah penghasil gerabah yang dikenal di Yogyakarta adalah di Kasongan, Bantul. Dari sejarahnya para pengrajin kasongan hanya membuat gerabah untuk fungsi peralatan dapur atau peralatan makan. Salah satu yang khas dihasilkan adalah kendil hitam untuk wadah gudeg. Gudeg adalah makanan khas Yogyakarta.

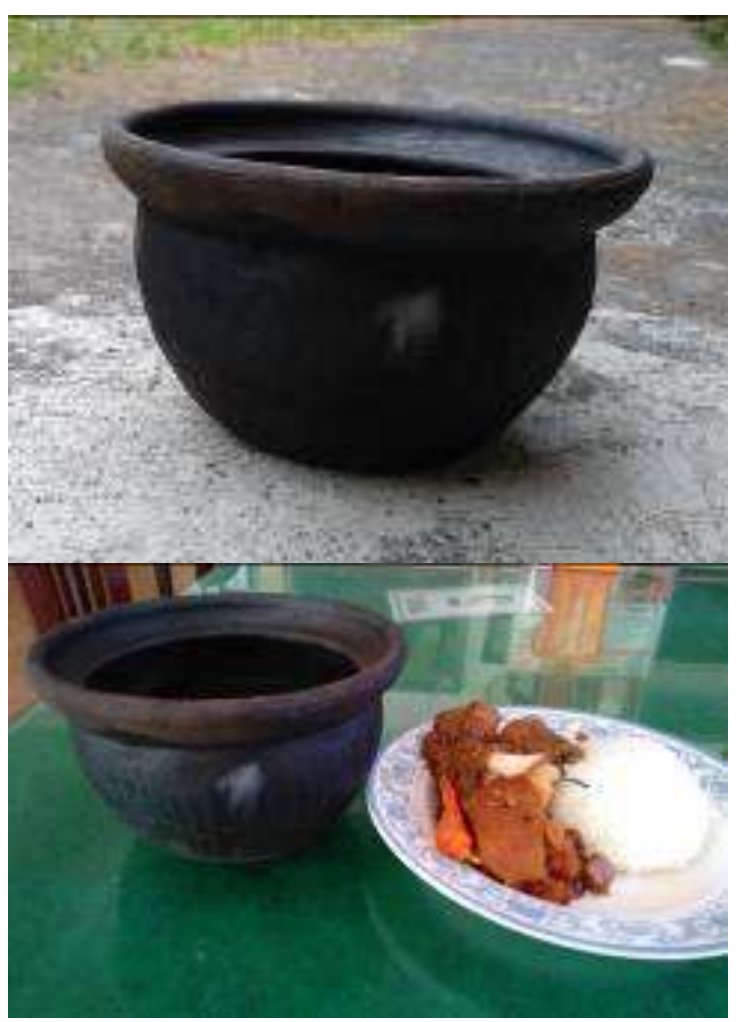

Gambar 1 \& 2: Kendil hitam \& Nasi gudeg

Gudeg Kendil sering menjadi oleh-oleh (buah tangan) khas Yogya yang dibeli oleh orang-orang luar kota yang berkunjung ke Yogyakarta untuk diberikan pada keluarga atau kerabatnya. Yogyakarta banyak dikunjungi pendatang karena dikenal sebagai kota pendidikan atau kota budaya. Kendil gudeg sengaja dibuat berwarna hitam melalui proses pembakaran ladang (field firing) secara tradisional. Dalam dunia keramik, disebut dengan pembakaran reduksi (reduction firing) yaitu berkurangnya oxygen dalam proses pembakaran menggunakan kayu bakar dan uwuh (daun-daun atau ranting kering). Kendil dibuat dari bahan tanah liat jenis earthenware, 
yaitu tanah merah yang banyak terdapat di sekitar (local material). Tanah liat earthenware atau teraccotta dibakar dengan suhu rendah sekitar $600^{\circ}-1050^{\circ} \mathrm{C}$, hasilnya akan berwarna merah. Kendil gudeg identik dengan kendil berwarna hitam.

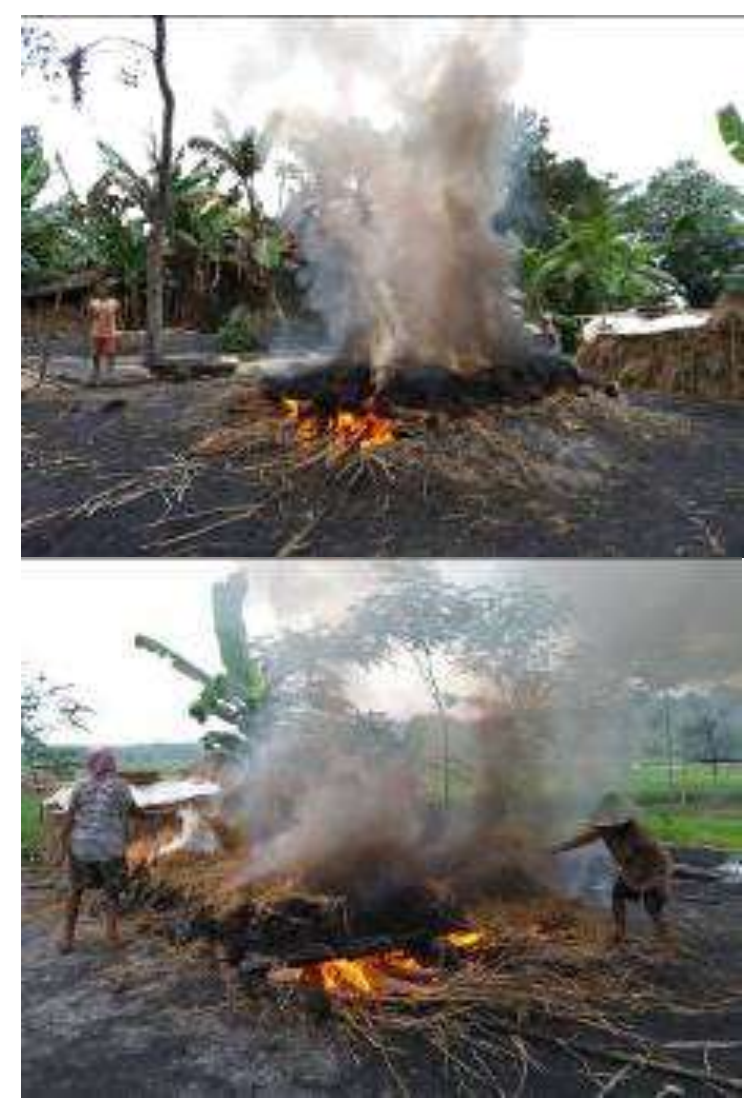

Gambar 3 \& 4: Pembakaran ladang (field firing)

Perkembangan jaman dengan
kemajuan teknologi dalam industri
menyebabkan membanjirnya produk peralatan rumah tangga dengan bahan logam, bahkan saat ini plastik menguasai segala jenis produk di dunia. Produk-produk berbahan plastik diantaranya peralatan: rumah tangga, dapur, makan, minum, meubel, alas kaki, fashion dan packaging (pembungkus). Dampak dari plastik kita pahami menyebabkan sampah yang tidak ramah lingkungan, karena tidak terurai dengan tanah dan air. Salah satu penyebab bencana banjir diantaranya disebabkan karena sampah plastik yang menimbun di saluran air, laut dan tentunya eco-system alam berubah drastis.
Kelangsungan hidup peralatan dapur berbahan tanah liat telah tergeser oleh produk-produk plastik atau bahan lain yang dianggap lebih praktis dan ringan. Di desa gerabah Kasongan khususnya, pengembangan desain gerabah sudah berubah banyak untuk fungsi hiasan interior dan eksterior. Pengerajin tradisional yang dulu membuat peralatan dapur sudah jarang, para pengrajin gerabah yang muda banyak yang menggunakan teknik cetak tekan menggunakan cetakan gipsum. Hal ini yang meresahkan penulis selain gipsum yang tidak mudah terurai dengan tanah, juga dapat punahnya teknik tradisional pembuatan gerabah. Secara akademik, pendidikan jurusan Kriya Keramik hampir semuanya mengajarkan teknik keramik modern dengan pewarnaan glasir dan menggunakan kiln (oven pembakaran) modern berbahan bakar gas. Para pelajar yang belajar keramik di sekolah, hanya tahu proses pembuatan keramik secara modern. Bahkan tidak jarang banyak siswa yang merasa bingung setelah lulus sekolah karena tidak punya biaya untuk membuat studio keramik. Mereka menganggap berkeramik harus menggunakan oven dan perlengkapan modern yang mahal, sehingga berhenti berkarya. Generasi milenial lupa akan nenek moyangnya yang menciptakan kendil untuk bertahan hidup dengnan bahan yang didapat di sekitar dan teknik yang ssangat sederhana.

\section{METODE PENELITIAN}

Penelitian yang dilakukan ini merupakan jenis penelitian kualitatif, seperti menurut pandangan John W. Creswell mengenai penelitian kualitatif yaitu:

"Penelitian kualitatif dimulai dengan asumsi dan penggunaan kerangka penafsiran/teoretis yang membentuk atau mempengaruhi studi tentang permasalahan riset yang terkait dengan makna yang dikenakan oleh individu atau kelompok pada suatu permasalahan 
sosial atau manusia. Untuk mempelajari permasalahan ini, para peneliti kualitatif menggunakan pendekatan kualitatif mutakhir dalam penelitian, pengumpulan data dalam lingkungan alamiah yang peka terhadap masyarakat dan tempat penelitian, dan analisis data yang bersifat induktif maupun deduktif dan pembentukan berbagai pola atau tema. Laporan atau presentasi tertulis akhir mencakup berbagai suara dari para partisipan, refleksivitas dari peneliti, deskripsi dan interpretasi tentang masalah penelitian, dan kontribusinya pada literatur atau seruan bagi perubahan", (2015)

Penelitian ini dimulai dari ketertarikan penulis akan gerabah, dan membawanya ke dalam studi etnografi sehingga penulis banyak meluangkan waktu di lapangan, mengumpulkan data dengan mengamati langsung (observasi) dan mendokumentasikan setiap proses yang ada secara mandiri dalam waktu lama.

Tujuan penelitian ini untuk mengetahui keberadaan kendil gudeg di "jaman now" era milenial ini. Apakah masih diminati atau sudah punah? Apa sebabnya? Bagaimana awal mula kendil diciptakan oleh nenek moyang? Dan bagaimana mere-aktualisasi kendil gudeg di era milenial?

Adanya penelitian ini diharapakan dapat memperkenalkan penciptaan kendil oleh pengerajin gerabah tradisional, mewariskan keahlian cara membuat gerabah tradisional, serta mengangkat "nilai survival life" dibalik pembuatan kendil (hitam) gudeg.

\section{KAIIAN PUSTAKA}

\section{Gerabah dan Sejarahnya}

Gerabah atau disebut juga sebagai tembikar dalam dunia arkeologi, adalah salah satu jenis keramik yang paling mudah dalam pengerjaan karena biasa menggunakan tanah liat lokal earthenware dengan suhu tidak perlu tinggi. Dengan pembakaran bersuhu rendah, maka gerabah sangat berpori (high pourousity) dan tidak mempunyai kekuatan tinggi seperti halnya keramik stoneware yang bersuhu tinggi. Karena tanah merah mudah di dapat di daerah Indonesia maka dapat ditemui banyak desa gerabah yang tersebar di Nusantara ini. Sedangkan kata keramik sendiri berasal dari bahasa Yunani yaitu "keramos" yang artinya: periuk atau belangan yang terbuat dari tanah liat. Jadi barang keramik adalah baranng yang dibuat dari bahan-bahan tanah merah (earthenware) atau batuan silikat (stoneware). Dan gerabah merupakan salah satu jenis keramik yang menggunakan tanah liat merah, disebut juga terakota. (Astuti, 1982) Tradisi membuat gerabah sudah dikenal manusia lebih dari 10.000 tahun yang lalu, dimana manusia mulai mengenal hidup bercocok tanam (neolitic), karena manusia mulai mengenal cara hidup menetap tidak nomaden merasakan kebutuhan akan persediaan bahan makanan untuk konsumsi selama waktu tertentu. Sehingga manusia mulai memikirkan membuat alat-alat rumah tangga dan ritual yang dibutuhkan. Gerabah menjadi alat yang penting untuk kehidupan manusia karena sifatnya yang tahan air dan tahan panas, sehingga cocok untuk tempat penyimpanan. Gerabah mempunyai dua fungsi penting dalam kehidupan manusia, yaitu sebagai fungsi kehidupan manusia (utilitarian) dan fungsi religius atau upacara (ceremonial). Gerabah dalam fungsi sebagai alat bertahan hidup yang ditemukan berupa alat keperluan sehari-hari seperti alat-alat rumah tangga untuk memasak makanan (cooking vessel) dan tempayan untuk tempat air atau menyimpan beras serta menyimpan biji-bijian (storage vessel). 


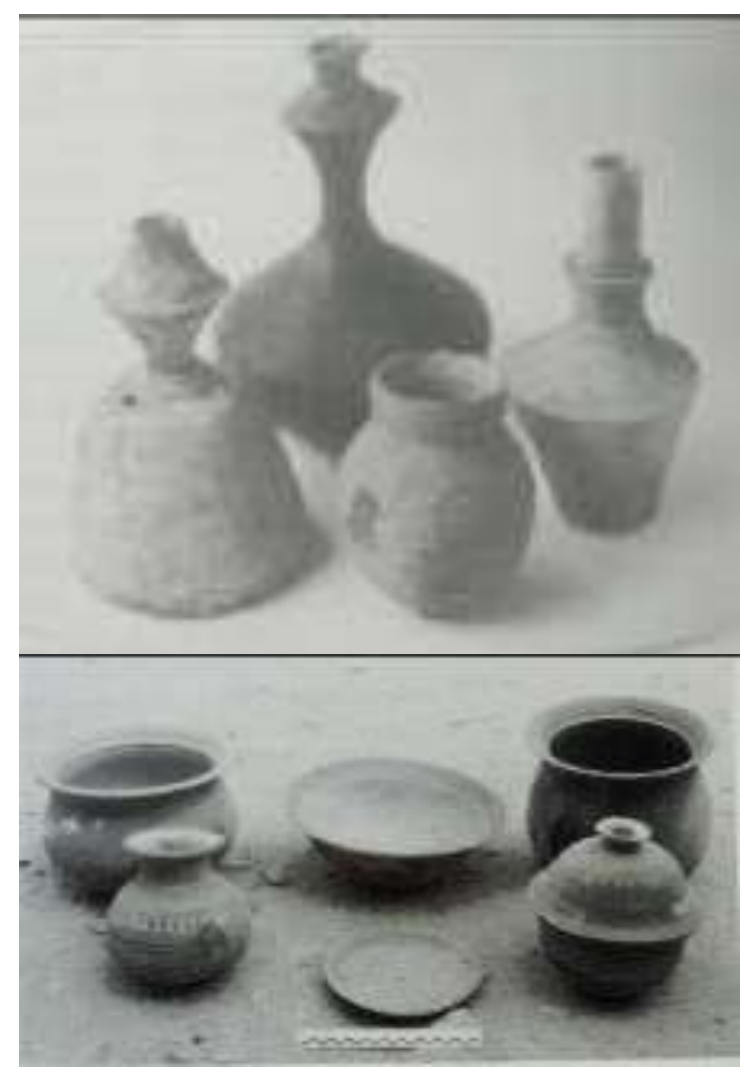

Gambar 5 \&6: Gerabah kuno sebagai peralatan kebutuhan rumah tangga

Sedangkan sebagai fungsi religius dikenal gerabah sebagai perlengkapan upacara sesuai kepercayaan masyarakat jaman prasejarah, seperti dalam upacara penguburan gerabah yang digunakan untuk bekal-kubur (burial-gift) atau wadah kubur disebut tempayan kubur (jar burial).

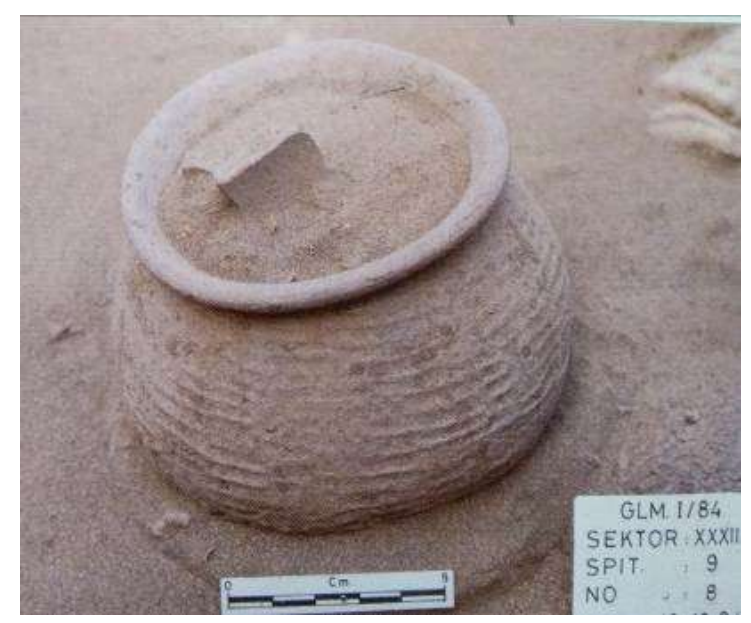

Gambar 7: Gerabah bekal kubur (sebagai tempat abu jenazah)
Dari penemuan arkeologi gerabah yang digunakan untuk pedupaan digunakan sekitar 1400 S.M. di Inggris, sedangkan gerabah sebagai alat upacara penguburan di Asia Tenggara dikenal sejak 2000 tahun silam, dan budaya gerabah di Indonesia dikenal antara 1500 S.M.- 400 M. Dengan penemuan gerabah dapat menunjukkan perkembangan budaya suatu masyarakat. Dibandingkan dari hasil budaya manusia yang lain, gerabah dikenal dalam kemudahan teknologi, karena gerabah terbuat dari bahan tanah liat (earthenware) yang terdapat di alam sekitar melalui proses pembakaran yang sangat tradisional, yaitu pembakaran ladang (field firing) dengan suhu pembakaran rendah, menggunakan bahan bakar uwuh (daun-daun dan ranting kering) yang terdapat disekitar. Tanah liat merupakan bahan yang universal, karena mudah didapat dimana-mana, mudah dibentuk dan bila dibakar menjadi benda keras yang disebut gerabah.

Diduga awalnya manusia membuat gerabah dengan bentuk yang meniru bentuk wadah batu atau wadah kayu, kemudian meniru keranjang bamu, dan berkembang jadi bentuk yang macam-macam. Awalnya bentuk sederhana berupa wadah beralas datar dengan dinding vertical, dan cawan bulat sederhana tanpa hiasan atau ornamen. Selanjutnya berkembang dengan bentuk yang lebih baik, wadah dengan rongga yang lebih luas seperti cawan dan periuk. Permukaannya kasar, tidak berhiasdan hasil pembakaran rendah. Dengnan ditemukannya budaya Hemudu di Yuyao (Cina) sekitar 7000 tahun silam memberi bukti-bukti itu. Gerabah itu kemudian berkembang dengan bentuk rongga lebih luas dengan teknik kumparan/putar, yang di duga untk peralatan dapur dan tempat makanan. Gerabah dengan bentuk lebih halus dan berhias berkembang pada dinasti Shang dan Zhou sesudah abad 16 S.M., sedang di Asia tenggara pada kebudayaan Sahuynh- 
Kalanay dan Bau-Melayu sekitar $750-1000$ S.M. Di Indonesia gerabah ditemukan di situssitus penguburan diantaranya: situs Plawangan (Jawa Tengah), Situs Gilimanuk (Bali), di melolo, Cipali dan lainnya yang terdiri dari bentuk: cawan, periuk, kendi bercerat dan kendi polos, serta tempayan.

Setelah manusia mulai mengenal tulisan gerabah berkembang dengan jenis berupa keren, anglo, lampu minyak kelapa (bahasa Jawa: cuplak) dan jenis non-fungsional berupa patung terakota, batu bata dan elemen bangunan lainnya. Kualitas lebih bagus, yaitu permukaan lebih halus, bentuk simetris dengan banyak menggunakan teknik rodaputar, bahkan mulai muncul keramik berglasir. Gerabah di Indonesia berkembang pada awal $\mathrm{M}$ hingga abad $14 \mathrm{M}$. Makin berkembang seturut masa berkembangnya pengaruh Hindu Budha pada $400 \mathrm{M}$ hingga $1600 \mathrm{M}$ antara lain dengan ditemukannya situs di Trowulan, Mojokerto (Jawa Timur) yang merupakan bekas kerajaan Majapahit dan situs-situs arkeologi lainnya. Pengaruh Islam di Indonesia (abad $15 \mathrm{M}$ ) pada erabah makin berkembang jenisnya seperti: pinggan, nampan dan lainnya, sedang kualitas hampir sama dengan sebelumnya. Peninggalan jaman Islam ditemukan di situs banten lama, Serang (Jawa Barat) dan lainnya.

Tradisi gerabah berkembang sampai saat ini di banyak daerah seperti di Asia dan Indonesia. Sekalipun posisi gerabah saat ini banyak diganti oleh wadah dari bahan-bahan lain seperti logam, plastik dan lainnya. Khususnya di Indonesia, beberapa daerah yang tersebar di Nusantara masih terdapat desadesa penghasil gerabah tradisional. Hasil gerabah hampir sama jenisnya yaitu berupa peralatan dapur antara lain: kendil, kuali, wajan/sangan, sangan bolong, luweng/pawon (tungku masak), kern, anglo, kendi dan cobek. (Soegondo, 1995) Masih cukup banyak masyarakat di pedesaan yang menggunakan alat-alat dapur itu, karena letak geografis, kondisi alam dan infrastruktur yang masih sulit dijangkau dengan kendaraan modern. Perkembangan desain ikut menambah keragaman pembuatan gerabah yang berfungsi sebagai pelengkap interior, seperti: tutup lampu taman dan ruangan, pot bunga, asbak dan barang hiasan yang lainnya. Teknik pembuatannya juga bermacam-macam seperti teknik: kumparan (coiling), tatap-landas (paddle dan anvil), roda-putar (potter's wheel) dan pijat tangan (pinching). Kualitasnya masih ada yang seperti dahulu, agak kasar dan ada yang halus. Di Indonesia tersebar daerah gerabah tradisional diantaranya: Mayong (Kabupaten Jepara, Jawa Tengah), Sambirata (Kabupaten Rembang, Jawa Tengah), Nyamplungan (Temanggung, Jawa tengah), Klipoh (Borobudur, Jawa tengah), Bayat (Klaten, Jawa tengah), Sampang (Cilacap, Jawa Tengah), Klampok (Banjarnegara, Jawa tengah), Kasongan (Bantul, Jawa tengah), Pemalang (Jawa Tengah), Plered (Purwakarta, Jawa Barat), Mojokerto (Jawa Timur), Ubung (Bali), Kapal (Bali), Banyumulek (Lombok), Gorontalo, Papua dan masih banyak lainnya.

\section{Gerabah Tradisional, Kendil Gudeg dan Nilai Hidup}

Kendil termasuk gerabah yang bentuk badannya bulat berongga, dengan leher yang lebih sempit ukuran diameternya dibanding badannya, dan berbibir melebar sehingga mudah memasukkan sayur atau bahan makanan ke dalamnya. Kendil karena ukuran lebih kecil dari kuali, maka fungsinya hanyalah sebagai wadah, bisa makanan kering atau berkuah. Sedangkan Kendil Hitam, adalah kendil yang dalam proses pembakaran memang sengaja dibuat berwarna hitam, alasannya adalah untuk menghilangkan bau tanah liat sehingga langsung dapat digunakan untuk wadah. Kalau yang masih merah biasa akan direndam atau diisi air selama kira-kira 
seminggu untuk menghilangkan bau tanah tersebut. Khusus untuk makanan gudeg digunakan kendil hitam juga untuk tidak menimbulkan warna berbeda/luntur dari reaksi dengan makanan gudegnya, karena menggunakan daun jati untu memberi warna coklat gudeg. Memperhatikan urutan proses pembuatan gerabah tradisional, khususnya kendil gudeg perlu ketekunan dan kesabaran tinnggi dari menyiapkan tanah liat, pembentukan, hingga siap di bakar. Urutan prosesnya antara lain sebagai berikut:

\section{a. Pengolahan Tanah Liat}

Tanah liat diperoleh dari tanah lokal Kasongan dicampur dengan pasir kali yang halus sebagai kerangka body. Pasir halus diambbil dari kali Bedog yang melintasi desa Kasongan. Tanah liat dan pasir dicari sendiri oleh pengrajin gerabah dan kemudian diijakinjak hinngga tercampur merata. Sudah beberapa tahunbelakangan karena bahan yang mulai berkurang di kasongan, sehingga didatangkan bahan tanah merah dari Godean, sehingga campuran 3 macam tanah diinjakinjak merata. Melihat proses menginjak-injak tanah liat sepertinya mudah, tetapi sebenarnya pekerjaan yang cukup berat karena tanah yang terlalu liat, sehingga si penginjak-injak mengeluarkan banyak tenaga sampai bercucuran keringat. Tetapi sekaligus membuat badan sehat ungkap beberapa pengrajin. Pengrajin yang sudah tua tentu saja sudah tidak kuat mencamur sendiri, beruntung sekarang sudah ada jasa penggilingan tanah liat menggunakan mesin berbahan bensin/solar. 1 gelondong kira-kira $10 \mathrm{~kg}$ dapat dibeli seharga $\mathrm{Rp}$ 6.000,-

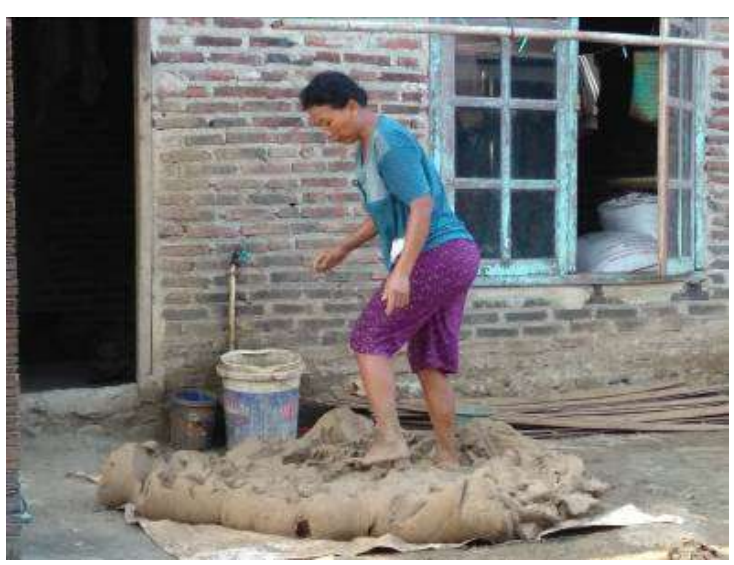

Gambar 8: Pencampuran tanah liat dan pasir kali dengan diinjak-injak.

\section{b. Pembentukan}

Tanah liat campuran kemudian dibentuk dengan teknik pilin besar dan kemudian dipipihkan dan dibentuk melingkar di atas meja putar sederhana. Kemudian di tambah lagi pilinan pipih di atasnya, begitu seterusnya meja di putar sembari ruas jari tangan menghaluskan tiap sambungan agar menyatu. Satu tangan menekan ke luar, satu tangan menahan ke dalam agar bentuk bulat stabil dan rata ketebalan dindingnya sambil di tarik ke atas perlahan mencapai ketinggian diinginkan. Kemudian bagian mulit di kecilkan untuk lehernya dan sambil ada bagian ditarik melebar ke luar sebagai bibir kendil. Proses pembentukan perlu konsentrasi tinggi. Di tahap ini ada penyatuan fokus antara mata, hati dan tangan agar tanah yang sedang dibentuk dapat simetris dan sempurna haasilnya.

\section{c. Pengeringan}

Setelah selesai, maka kendil yang masih basah di angin-anginkan. Karena campuran tanah yang mempunyai struktur kuat sebagai kerangka body maka biasanya bisa langsung di jemur dibawah matahari, tetapi tidak terlalu lama untuk dilanjutkan dibentuk. Sampai pada tingkat kering tertentu kemudian di ambil, satu persatu gerabah yang setengah kering dilanjutkan dbentuk bagain dalam agar lebih 
halus dan lebar, yaitu dengan diketuk-ketuk menggunaka batu bulat.

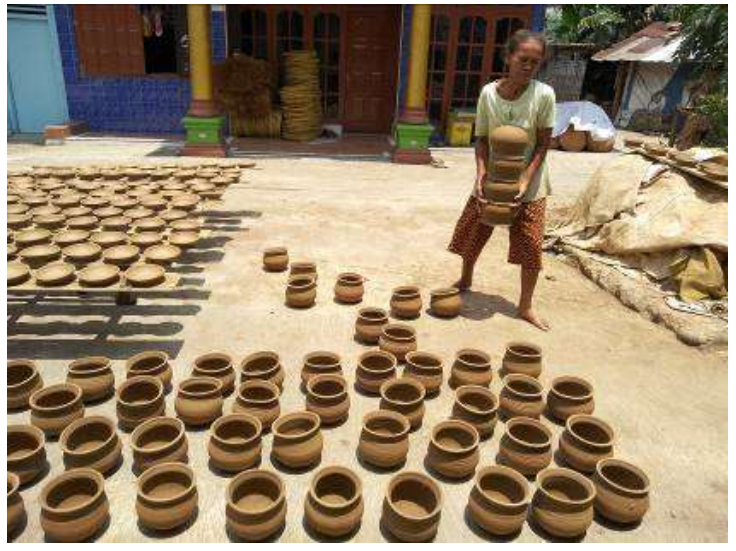

Gambar 9: Menjemur kendil

\section{d. Penghalusan}

Setelah mencapai bentuk dan ukuran diinginkan maka di jemur kembali. Sebelum terlalu kering maka diambil dan dihaluskan satu persatu menggunakan batu halus yang pipih, proses ini di sebut sangkling, membuat permukaan luar kendil mengkilap (semi glossy).
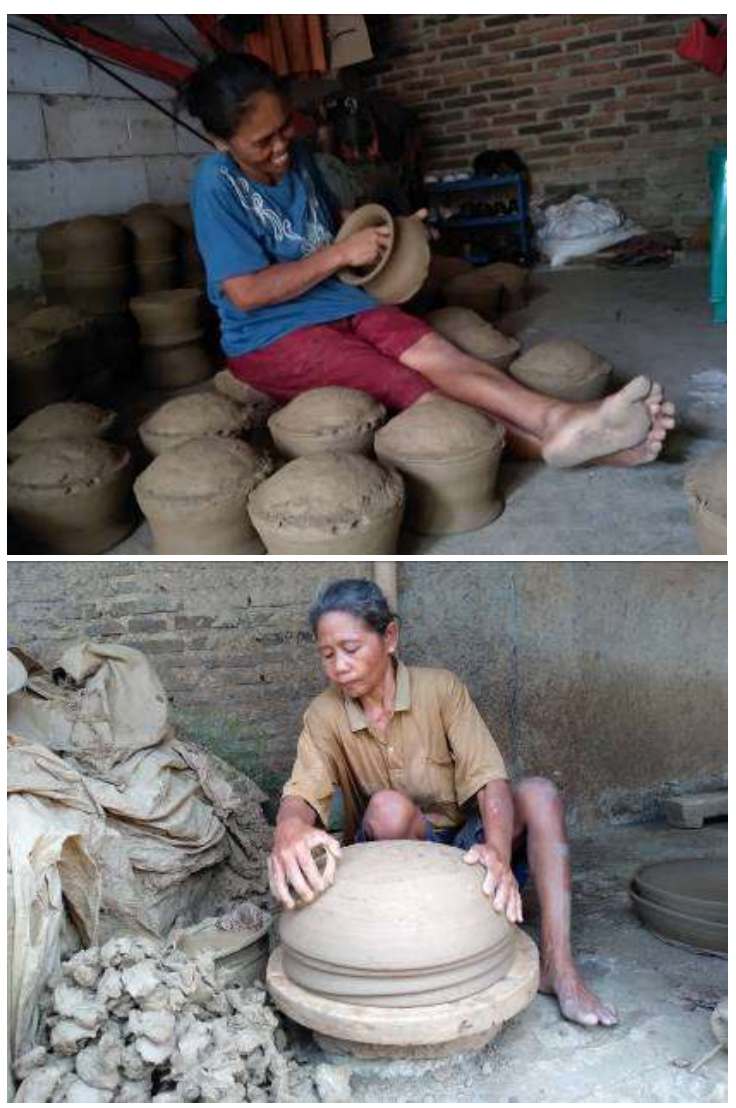

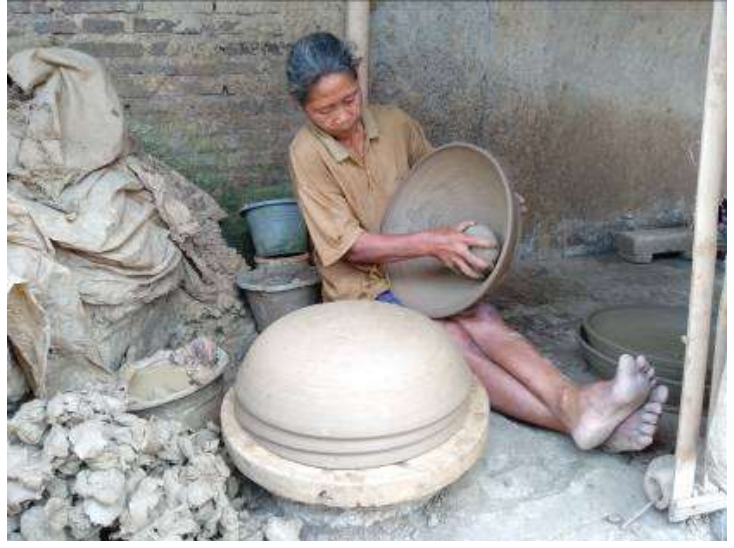

Gambar 10, 11 \& 12: Beberapa roses finishing (penghalusan)

\section{e. Pembakaran}

Setelah halus kemudian di jemur lagi hingga magel (kuat tetapi belum terlalu kering) untuk siap di bakar dengan cara disusun di atas batang kayu atau alas yang lebih tinggi dari tanah sekitar 20-30 cm agar ada rongga memasukkan bahan bakar kayu di bagian bawahnya. Setelah gerabah di susun rapi kirakira 2 lapis, maka ditimbun jerami atau sekam padi yang kering di atasnya sampai tertutup semua, barulah api dinyalakan baik di atas maupun dari bawah. Terus jerami dan kayu disiapkan untuk menyalakan api yang tidak boleh padam sebelum gerabah terbakar membara, maka api harus tetap ada. Setelah gerabah membara, barulah api didiamkan mati.

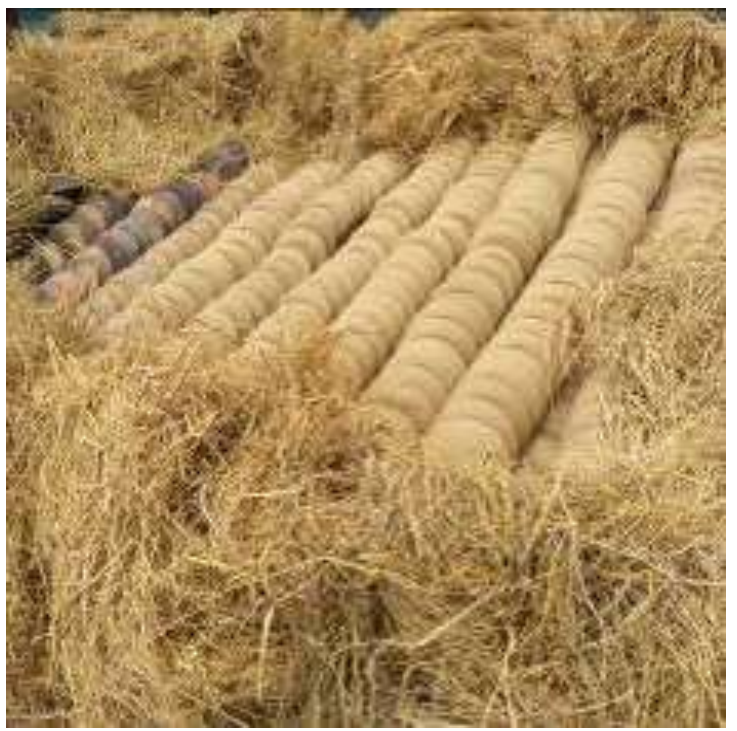



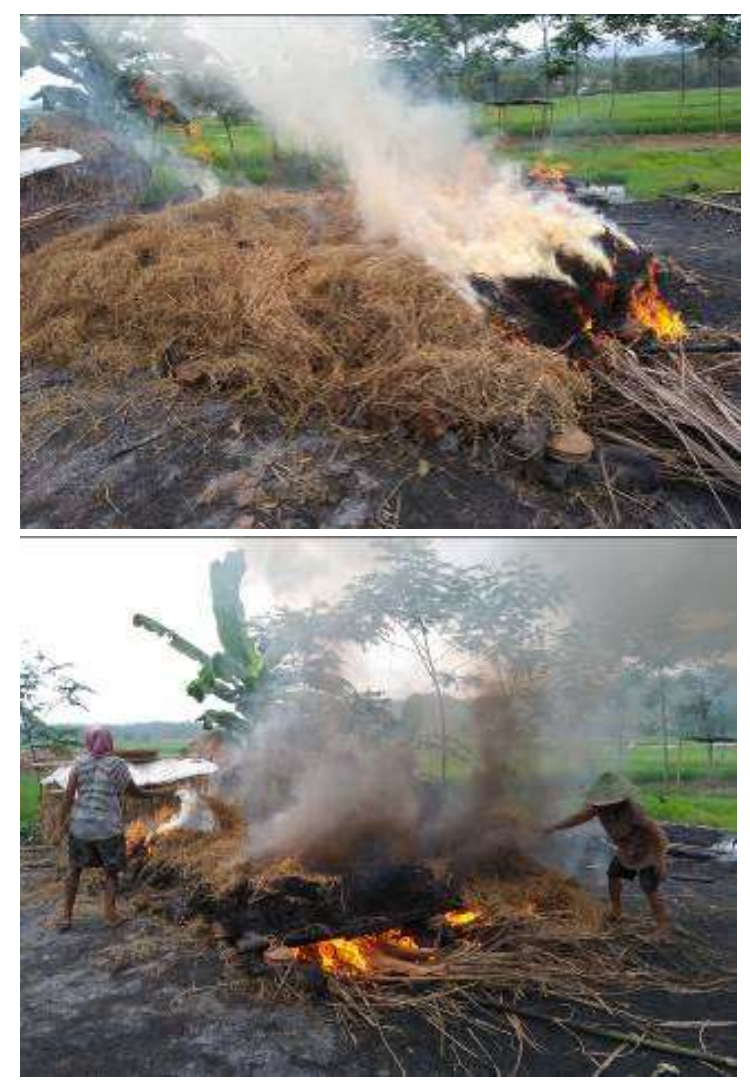

Gambar 13, 14 \& 15: proses pembakaran ladang (field firing)

\section{f. Penghitaman}
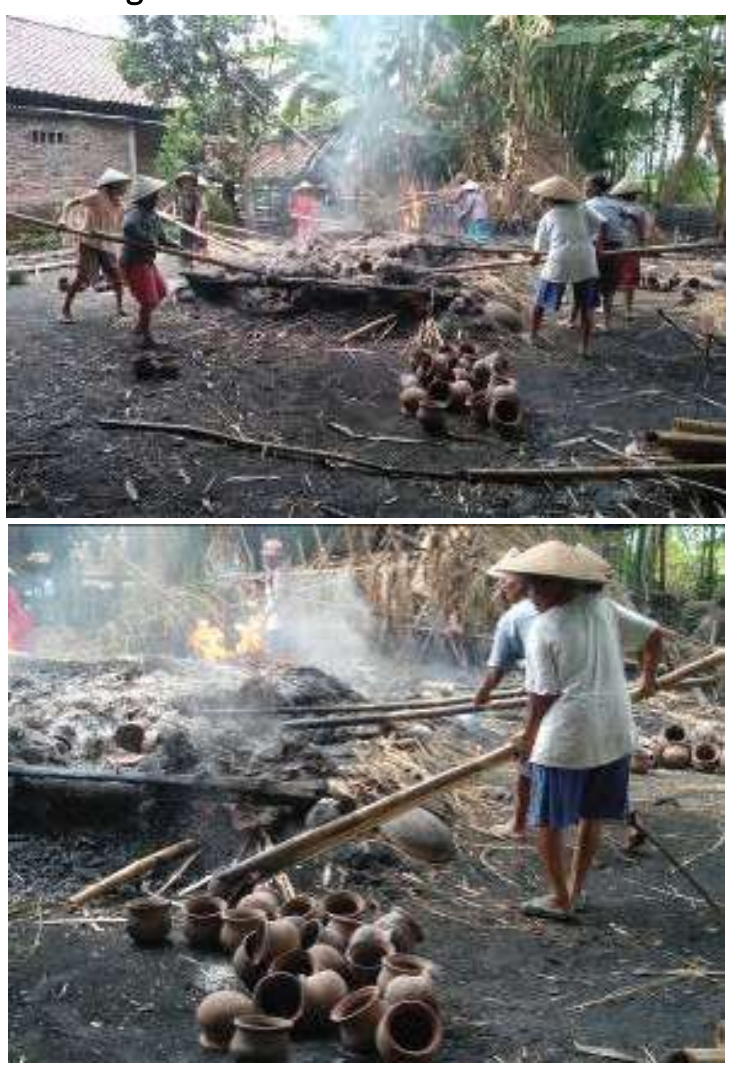

Gambar 16\&17: Menyumpit (mengangkat) gerabah yang sudah matang untuk diproses hitam (reduksi)
Gerabah yang masih menyala diangkat satu persatu menggunakan batang bambu panjang agar uap panas tidak menyengat di wajah pengrajin yang mengambilnya. Gerabah diangkat dan dimasukan dalam timbunan uwuh (sekam atau daun kering) hingga body gerabah yang menganga berubah menjadi hitam, dan segera diangkat dijauhkan dari uwuh yang mulai terbakar, gerabah hitam diletakan ditanah hingga dingin.

\section{g. Pemasaran}

Setelah jadi, kendil hitam disetorkan pengerajin ke pengepul, dengan harga Rp $1.500,-$, kemudian dari pengepul akan dijual ke pasar atau pemesan (pedagang gudeg) dengan harga Rp 2.000,- - Rp 2.500,- dan dari pedagang pasar akan dijual ke konsumen seharga Rp4.000,-- Rp 6.000,--

Melihat proses kerja yang tidak mudah itu dan perlu berhari-hari pengerjaan, apalagi di musin penghujan membutuhkan waktu lebih lama untuk pengeringan gerabahnya, maka tidak sebanding dengan uang yang diperoleh. Dari dulu hingga saat ini mengapa para pengrajin gerabah masih tergolong miskin. Mereka tidak menghitung biaya tenaga kerja dan bahan yang mudah di dapat. Padahal di mancanegara kerajinan hand-made dihargai tinggi di banding produk industri massal. Nilai ekonomi pada gerabah diciptakan karena kebutuhan fungsi, bukan menjadi tujuan komoditas yang seimbang dengan nilai tukarnya. Dibalik nilai fungsi gerabah, nilai tenaga kerja tidak dilihat atau tidak diperhitungkan. Kerajinan tradisional sering besar kecilnya nilai ditentukan sepihak oleh subyek pengguna, sedangkan pembuat hanya sebagai objek yang lemah tak berdaya menentukan nilai ekonomi barang yang dihasilkan. Jadi ada jarak yang tidak dapat di atasi, di mana nilai objek ditentukan sepihak, bukan timbal-balik antara pembuat dan pembeli. (Appandurai, 1986) 
Dalam pemasaran gerabah tradisional sering terjadi harga ditentukan oleh "pengepul" (perantara) antara pembuat dan konsumen. Terjadi beberapa tingkat rantai distribusi pemasaran gerabah, yaitu: pembuat (produsen) - pengepul (distributor) pedagang pasar (agen) -konsumen. Terkadang dari pengepul ada beberapa tingkat lagi hingga kea gen, dan dari age nada beberapa tingkat untuk sampai ke konsumen.

\section{RE-AKTUALISASI KENDIL GUDEG Teknologi Tepat Guna}

Keberadaan kendil hitam yang lazim digunakan sebagai wadah makanan khas Yogya: gudeg, mengalami penurunan sejalan dengan kemajuan teknologi. Teknologi yang maju pesat dalam industri massal, menawarkan wadah dari berbagai bahan seperti logam dan plastik. Barang-barang plastik dari China memanjiri pasar dunia. Teknologi tradisional pembuatan gerabah tentu saja kalah dengan kecepatan mesinmesin yang berjalan cepat dapat menghasilkan produk secara besar-besaran. Bahkan dalam dunia kuliner, khususnya gudeg banyak penjual gudeg mengganti wadahnya menggunakan bahan kardus (cartoon boxes), dan plastik (plastic container), juga besek (anyaman bambu)

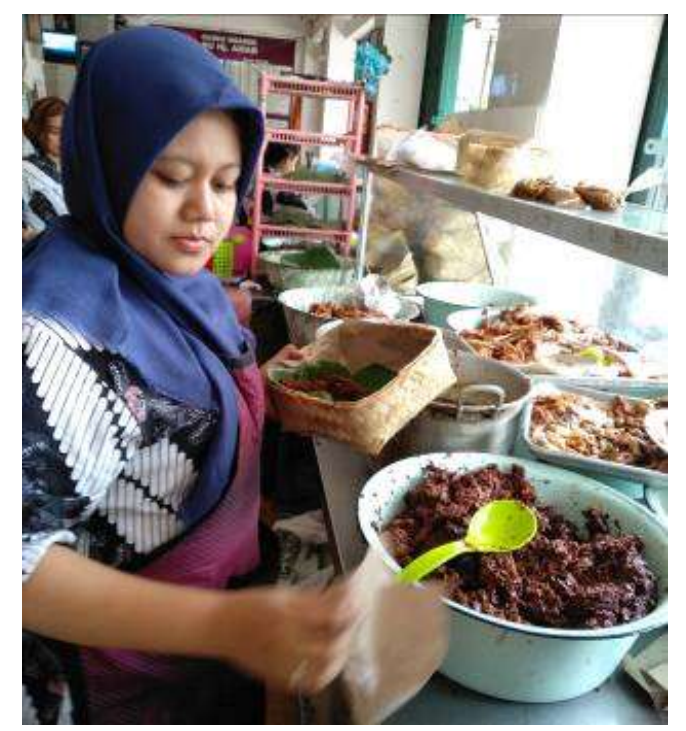

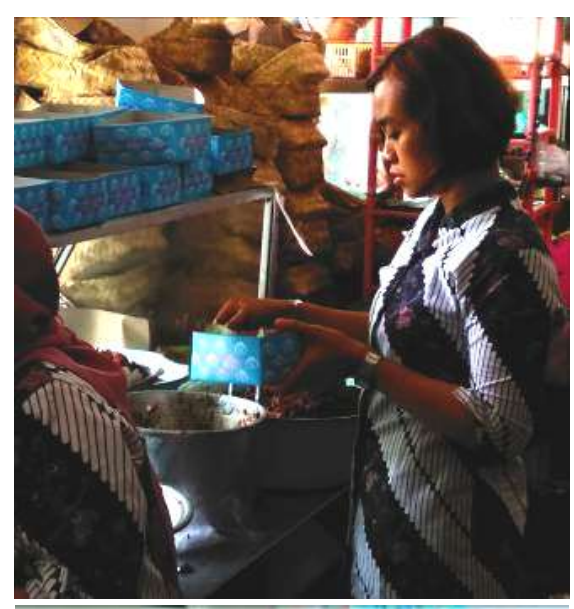

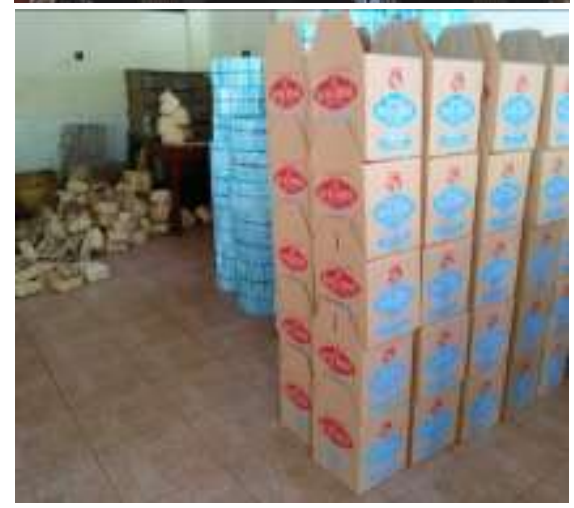

Gambar 18, 19\&20: macam-macam wadah gudeg saat ini (kardus dan "besek" anyaman bambu.

Lalu, bagaimana mere-aktualisasi keberadaan kendil hitam ini? Dalam dunia desain saat ini sedang mengkampanyekan tentang issue green-design, yaitu gerakan yang mengajak para desainer dan pemakai (user) mulai memikirkan keselamatan alam dan bumi ini. Jadi, manusia diajak lebih bijaksana dalam memilih desain-desain yang akan diciptakan maupun digunakan sehingga tidak akan berdampak merusak alam dan bumi. Penggunaan bahan plastik khususnya, dan teknologi produksi yang digunakan dianggap sangat berbahaya bagi alam. Bahan plastik tidak bisa terurai dengan tanah, begitu pula dalam teknik produksi massal menggunakan mesin-mesin yang membutuhkan energi listrik besar sangat membebani alam dan bumi yang kita pijak. Belum lagi produk dan alat-alat lain yang menggunakan bahan-bahan sintetis (kimia) dan berdaya besar, berbahaya untuk kelangsungan hidup kehidupan alam dan 
manusia. Dalam buku teknologi kampungan (1982), seorang warga California (Amerika) bernama Craig Thorburn justru mengagumi dan mempelajari teknologi tradisional yang ada di Indonesia. Menurutnya alat dan teknologi kampungan yang terlihat sederhana dan cenderung hampir punah, merupakan teknologi yang sarat akan nilai-nilai localwisdom karena sesuai kebutuhan manusia dan ramah lungkungan. Bahan yang digunakan banyak menggunakan bahan yang ada di alam sekitar, seperti kayu, bambu, tanah liat. Di sana dia melihat adanya local genius dalam manusia pedesaan membuat alat sesuai kebutuhan bertahan hidup sehari-hari, seperti: alat pertanian, perikanan, perkakas masak, pengangkutan, arsitektur (rumah dan konstruksi), industri kecil dan kerajinan tangan. Selanjutnya teknologi tradisional yang tersebar di Indonesia disebutnya sebagai "teknologi tepat guna", yaitu tidak hanya memandang alat dan teknologinya saja, tetapi merupakan teknologi yang sesuai dengan keadaan mereka masing-masing. Self determination teknologi sangat penting sebagai identitas budaya dan politik kemandirian. Teknologi yang bijaksana adalah yang mencari sesuai dengan lingkungan biologis, budaya dan ekonomi tertentu dimana mereka gunakan. Tidak berhubungan dengnan subsistensi dan ekonomi pasar. Di abad 20an ini penduduk di banyak negara berkembang dan hidup membaur antara ekonomi dann kebutuhan hidup melalui gadget modern. Penduduk desa masih menyediakan sebagian besar kebutuhan mereka sendiri, tidak terisolasi dari inovasi baru dan manfaat lain melalui perdagangan domestik dan internasional. (Thorburn, 1982)

Saat ini orang desa yang masih memproduksi alat yang mereka gunakan dianggap terbelakang, tidak logis atau primitif. Kita lihat di Kasongan kerajinan gerabah dengan teknik tradisional sudah berkembang sesuai kebutuhan baik alat dan tekniknya. Teknik putar sudah beralih ke teknik cetak (molding) dan pembakaran lading beralih ke tungku bak. Gerabah Kasongan tidak hanya di produksi untuk kebutuhan lokal, tetapi berkembang ke pasar internasional. Dengan demikian dapat kita pelajari, bahwa orangorang mancanegara justru mulai menyadari akan nilai ekonomi kerajinan hand-made yang justru bernilai ekonomi tinggi di negaranya. Begitu juga wadah makanan berbahan alam seperti kendil hitam, justru tetap punya nilai fungsi lebih aman dan higienis disbanding wadah berbahan logam dan plastik. Di kotakota besar mulai diminati pola makan sehat (vegan-food) dan obat herbal yang menggunakan wadah gerabah untuk menyajikan atau memasaknya. Hotel-hotel bertaraf internasional dan rumah makan mewah pada menawarkan suasana dan makanan khas pedesaan, karena penduduk kota yang sudah terbiasa dengan gaya hidup modern justru rindu akan suasana natural gaya pedesaan. Gaya pedesaan saat ini diminati konsumen, tampak mulai menjamurnya tempat-tempat kuliner yang menawarkan menu masakan desa. Bahkan ada yang menseting interior ruang makan bergaya kumuh suasana dapur tradisional, berdinding gedeg anyam bambu dan beratap rumbia lengkap dengan tungku masak tradisional: anglo dan luweng/pawon. Lokasi yang terpencil di tengah sawah atau perkampungan tetap akan dicari orang-orang perkotaan bahkan mancanegara.

Kendil hitam sengaja di buat berwarna hitam melalui teknik pembakaran tradisional, dengan maksud agar menghilangkan bau tanah yang sangat melekat sehingga dapat langsung dapat digunakan untuk wadah makanan (gudeg). Kendil yang terbuat dari tanah liat earthenware dengan pembakaran suhu rendah sehingga mempunyai tingkat porusitas besar (menyerap air) sebenarnya 
justru bagus untuk menyimpan makanan agar tidak cepat basi. Berbeda dengan makanan yang di simpan dalam wadah berbahan logam terutama dalam plastik makanan akan cepat basi, karena dinding wadah yang tertutup atau tidak pourous (tidak mempunyai pori-pori).

\section{Unsur Pendidikan dalam Proses Pembuatan Gerabah}

Tradisi keahlian membuat gerabah diwariskan secara turun-temurun tanpa diajarkan secara khusus (formal) oleh nenek moyang pada generasi penerusnya, anak dan cucu. Proses belajar yang disebut prinsip 3N oleh Ki Hadjar Dewantara ini meliputi tiga tahap, yaitu: ndelok (melihat), niteni (memperhatikan) dan niroke (menirukan). Hal ini menyebabkan bentuk gerabah yang tampaknya tidak ada perubahan berarti sejak dulu hingga kini, seolah seperti monoton. Tetapi sebenarnya dalam praktek pembuatannya ada proses belajar yang disebut ada "wirama" (ritme). Dalam wirama ada ke-indah-an. (Ki Hadjar Dewantara, 1977). Kehidupan masyarakat desa sangat nrimo ing pandum (menerima apa adanya), hidup dekat dengan alam, berbeda dengan manusia modern di perkotaan yang hidupnya serba terburu-buru, serba cepat. Masyarakat di pedesaan benar-benar menikmati setiap proses yang membutuhkan perhitungan detail, seperti pengrajin gerabah yang selalu memperhatikan keseimbangan antara: air dan tanah liat agar tanah siap dibentuk, dan proses pengeringan tanah sebelum dibakar melalui diangin-anginkan, tidak langsung dijemur matahari agar tidak retak, mengumpulkan bahan bakar uwuh (daun-daun atau ranting kering) untuk membakar gerabah, serta membakar di ladang (field firing) dengan bertahap dalam menaikkan suhu panasnya agar tidak pecah barang-barang yang dibuatnya. Kegiatan menjemur dan membakar sangat memperhatikan cuaca alam yang ada antara: kemarau dan penghujan, sehingga mereka sudah mempersiapkan berhari-hari bahkan berbulan-bulan, termasuk kegiatan mencari uwuh (daun dan ranting kering untuk bahan bakar). Dalam proses persiapan bahan untuk membuat gerabah hingga pembakaran ada penggabungan 5(lima) unsur yang harus seimbang antara: tanah (liat), air, udara, kayu dan api. Diperlukan keseimbangan maksimal untuk menghasilkan karya yang diharapkan atau hasil bagus.

Tanah liat, merupakan bahan alam yang sering disebut sebagai simbol ibu (perempuan), sedangkan langit (udara) sebagai simbol bapak (laki-laki). Ada nilai filosofi dalam kegiatan membuat gerabah dari pengolahan bahan hingga pembakarannya, selain diperlukan keseimbang antara 5 unsur alam, ada juga keseimbangan antara kegiatan antara aktivitas perempuan dan laki-laki (symbol langit dan bumi), dimana para perempuan diposisi sebagai pengrajin dan lakilaki di posisi mencari bahan bakar dan memasarkan. Pembuat gerabah di banyak daerah dilakukan oleh kaum perempuan (ibu rumah tangga), di samping menyelesaikan pekerjaan rumah tangganya, seperti memasak, mencuci pakaian, menyapu halaman dan mengasuh anak. Kegiatan membuat kerajinan gerabah sekaligus merupakan kegiatan bersosialisasi dengan tetangganya, seperti dalam proses mencampur tanah liat dengan pasir dengan cara diinjak-injak, kadang anggota keluarga bahkan tetangga ikut membantu. Kerja secara gotong-royong sangat terlihat saat proses membakar, sering dilakukan bergantian atau bersama yang bertujuan menghemat biaya pembakaran. Bahkan mereka seperti tidak pernah memberi nilai pada tenaganya dalam bekerja, sehingga harga jual gerabah sangat murah. Berbeda dengan kehidupan di kota yang bekerja individual, asal ada uang semua beres, anakanak diasuh oleh seorang pengasuh (baby- 
sitter) atau dititipkan pada jasa penitipan anak, sementara orang tua bekerja di kantor, pulang sore hari dalam kondisi sudah lelah. Jadi para pengerajin gerabah justru punya banyak waktu bersama anak dan keluarganya.

Proses pembentukan gerabah membutuhkan konsentrasi dan kepekaan indera manusia melalui motorik kasar dan halus, semua ruas jari, telapak tangan, hati dan pikiran dan mata perlu konsentrasi penuh untuk menghasilkan karya yang baik. Keseimbangan motorik kasar dan halus diperlukan bekerja bersama melalui kepekaan ruas-ruas jari dan telapak tangan dalam merasakan tebal-tipis dinding, menarik tinggirendah dan lebar-sempit ukuran yang diinginkan agar tercapai bentuk yang sempurna. Jadi ada proses yang melatih agar seseorang konsentrasi dan tidak emosional. Dari proses pencampuran tanah liat dengan air agar tanah plastis mudah dibentuk; bersatunya kerja ruas-ruas jari tangan, otak dan perasaan; proses pengeringan (sebelum dibakar) yang bertahap agar mudah di finishing sebelum benar-benar mengeras; sampai tahap pembakaran ladang di halaman rumah perlu di perhitungkan cara menaikkan suhu panas yang bertahap pelan agar gerabah tidak pecah karena thermal shock (perubahan temperature). Semua proses sebenarnya mengandung wirama atau irama yang halus atau perlahan, tidak tergesa-gesa. Hal ini tidak disadari telah melatih kepekaan inderawi para pembuat gerabah, sehingga tidak disadari ilmu pengetahuan di wariskan secara turuntemurun karena adanya proses kulinan (kebiasaan yang terus menerus) dari melihat, mengamati, dan meniru sebagai prinsip belajar $3 \mathrm{~N}$.

\section{PENUTUP}

Fenomena arus global yang sedang melanda dunia, khususnya pada generasi muda (generasi milenial) saat ini telah menimbulkan banyak masalah dalam kelestarian alam, bumi serta kehidupan manusia. Manusia perkotaan menjadi sangat individual, gaya hidup konsumtif, mengutamakan rasio/logika tetapi kehilangan empati dan intuisi. Pendidikan di sekolah banyak mengedepankan teori dengan banyak hafalan-hafalan, sehingga 3 elemen pokok dalam pendidikan: affective, cognitive dan psychomatoric tidak seimbang. Tetapi proses pendidikan dalam belajar membuat gerabah tradisional ketiga unsur itu bisa dicapai secara seimbang. Cognitive, adalah kemampuan peserta didik dalam menyampaikan kembali materi atau pengetahuan melalui tahap: memahami, menerapkan, menganalisa, mensintesa, dan mengevaluasi. Affective, bagaimana sikap dan cara peserta didik menilai dalam menerima ilmu pengetahuan. Dan Psychomotorik, merupakan kompetensi menerapkan ilmu yang diberikan guru. Ketiga elemen pendidikan tersebut dikenal sebagai: "Taksonomi Bloom". Bangsa kita sudah lama telah punya sistem pendidikan tersebut, khususnya di daerah pedesaan. Budaya dan karakter bangsa berkembang melalui pendidikan hati, otak dan fisik melalui warisan membuat gerabah tradisional. Di sinilah letak re-aktualisasi kendil hitam. Masyarakat pengrajin kendil hitam (gerabah tradisional) telah menciptakan budaya sosial yang tinggi, Pengalaman menemukan bahan lokal, alat dan teknologi yang sesuai alam pedesaan dalam menciptakan produk gerabah, membentuk budaya khas: sederhana, out-door dan kebersamaan (gotong-royong).

\section{Daftar Pustaka}

Appadurai, Arjun. 1986. "The Social Life of Things: Commodities in Cultural Perspective". London: Cambridge University Press.

Astuti, Ambar. 1982. "Teori Keramik I". Yogyakarta: Liberty. 
2008. "Keramik: Bahan, Cara

Pengerjaan Glasir". Yogyakarta: Arindo Nusa Media.

Cassierer, Ernst. 1987. "Manusia dan Kebudayaan: Sebuah Esei Tentang Manusia". Jakarta: Gramedia.

Creswell, John W. 2015. Penelitian Kualitatif \&

Desain Riset Memilih diantara Lima Pendekatan. Yogyakarta: Pustaka Pelajar.

Majelis Luhur Persatuan Taman Siswa. 1977. "Ki Hadjar Dewantara: Pemikiran, Konsepsi, Keteladanan, Sikap Merdeka I", Yogyakarta.

Riegger, Hal. 1970. "Raku: Art \& Technique". New York: Van Nostrand Reinhold Company.

Sarosa, Samiaji, S.E., M.Info.Sys., Ph.d. 2017. "Penelitian Kualitatif - Dasar-Dasar". Jakarta: Indeks.

Soegondho, Santoso. 1995. "Tradisi Gerabah di Indonesia - Dari Masa Prasejarah Hingga Masa Kini". Jakarta: P.T. Dian Rakyat.

Thorburn, Craig. 1982. "Teknologi Kampungan". USA: The Appropriate Technology Project of Volunteers in Asia.

Widagdo. 2005. "Desain dan Kebudayaan". Bandung: ITB. 